УДК 665.528.1

\title{
ОПРЕДЕЛЕНИЕ БИОЛОГИЧЕСКОЙ АКТИВНОСТИ ЭФИРНЫХ МАСЕЛ С ПОМОЩЬЮ БИОТЕСТ-СИСТЕМ IN VITRO
}

\author{
(C) В.А. Дубинская ${ }^{1}$, Н.А. Поляков ${ }^{1 *}$, А.А. Ефремов ${ }^{2}$, Е.А. Ефремов ${ }^{2}$ \\ ${ }^{1}$ Всероссийский научно-исследовательский институт лекарственных \\ и ароматических растений, ул. Красина, 2, Москва, 123056 (Россия), \\ e-mail:polakov@yandex.ru \\ ${ }^{2}$ Сибирский федеральный университет, пр. Свободный,79, Красноярск, \\ 660041 (Россия), e-mail: AEfremov@sfu-kras.ru
}

\begin{abstract}
Показана возможность применения ферментных тест-систем in vitro для выявления биологической активности эфирных масел и сравнительного анализа различных фракций эфирного масла. Эфирное масло пихты и сосны сибирской активируют ферменты системы антиоксидантной защиты каталазу и глутатионредуктазу КАТ и ГР и ингибирует АХЭ, что свидетельствует о наличии в исследуемых эфирных маслах антиоксидантных и ноотропных свойств. Установлено, что при перегонке с водяным паром биологическая активность эфирного масла может как увеличиваться, так и снижаться, что определяется влиянием химических соединений в составе отдельных фракций эфирного масла.

Ключевые слова: пихта сибирская (Abies Sibirica), сосна сибирская (Pinus Sibirica), эфирное масло, ферментные биотест-систем in vitro, биологическая активность.
\end{abstract}

\section{Введение}

Разновидностью высокоэффективных биологически активные веществ (БАВ) являются эфирные масла, представляющие собой смесь душистых летучих веществ, образующихся в растениях и относящихся к различным классам органических соединений, преимущественно терпеноидам, реже к ароматическим и алифатическим соединениям. Эфирные масла обладают широчайшим спектром биологической активности (противомикробным, противовоспалительным, отхаркивающим и мочегонным свойствами, а также спазмолитической активностью и седативным действием), широко используются в ароматерапии и производстве пищевых продуктов, изделиях бытовой химии, применяются как растворители (скипидар) и компоненты парфюмерных и косметических средств, внедрятся в фармацевтическую промышленность, медицину [1].

Получение эфирного масла перегонкой с водяным паром длиться не менее 4 ч. В процессе выделения эфирного масла из растительного сырья химический состав получаемого масла может меняться, так как с увеличением времени отгонки возрастает доля труднолетучих соединений, а концентрация легколетучих компонентов по мере выделения масла - уменьшается [2-6]. Поэтому для выявления наиболее ак-

Дубинская Валентина Алексеевна - заведующая отделом биомедицинских технологий, кандидат биологических наук, тел.: (495) 2544636, e-mail: va@ diamsoft.ru Поляков Николай Александрович - ведущий научный сотрудник, кандидат биологических наук,

e-mail: polakov@yandex.ru

Ефремов Александр Алексеевич - заведующий лабораторией хроматографических методов анализа центра коллективного пользования, доктор химических наук, професcop, e-mail: AEfremov@ $\mathrm{sfu}$-kras.ru

Ефремов Евгений Александрович - аспирант тивных фракции эфирного масла и определения влияния изменений химического состава на их биологическую активность, лучше подходят экспрессметоды, к которым относятся биотест-системы in vitro. Разработанные в ВИЛАР молекулярные тестсистемы in vitro, в которых в качестве тест-объектов применяют ключевые или лимитирующие ферменты, позволяют проводить направленный и сравнительный поиск наиболее активных БАВ [7].

\footnotetext{
* Автор, с которым следует вести переписку.
} 
Цель работы - определение биологической активности эфирного масла и отдельных фракций, выделенных из растительного сырья пихты (Abies Sibirica) и сосны сибирской (Pinus Sibirica).

\section{Материаль и методы}

В качестве материалов исследования использовали эфирное масло пихты сибирской и сосны сибирской, полученное из древесной зелени соответствующих деревьев Красноярского края. Компонентный состав полученных масел и их отдельных фракций был определен ранее с использованием хромато-масс-спектрометрии [35]. Биологическую активность исследуемых эфирных масел определяли с помощью молекулярных тест-систем in vitro, в которых в качестве тест-объектов использовали ферменты системы антиоксидантной защиты: глутатионредуктазу (ГР) и каталазу (КАТ), а также фермент ацетилхолинэстеразу (АХЭ) [7].

В работе использовали лиофилизированные препараты ферментов.

Каталитическую активность каталазы определяли по скорости разложения субстрата - перекиси водорода $\left(\mathrm{H}_{2} \mathrm{O}_{2}\right)$. В состав реакционной смеси входил фосфатный буфер $(\mathrm{pH} 7,8), \mathrm{H}_{2} \mathrm{O}_{2}$ в концентрации 0,03\%, концентрация фермента составляла 0,2 мкг/мл. Продолжительность реакции разложения субстрата $\left(\mathrm{H}_{2} \mathrm{O}_{2}\right)$ ферментом 5-10 мин. Реакцию останавливали добавлением в реакционную смесь аммонния молибденовокислого $\left(\left(\mathrm{NH}_{4}\right)_{6} \mathrm{Mo}_{7} \mathrm{O}_{24} \cdot 4 \mathrm{H}_{2} \mathrm{O}\right)$. Оставшуюся перекись водорода измеряли в виде комплекса с $\left(\mathrm{NH}_{4}\right)_{6} \mathrm{Mo}_{7} \mathrm{O}_{24} \cdot 4 \mathrm{H}_{2} \mathrm{O}$ на спектрофотометре Shimadzu MPS-2000 при $\lambda=410 \mathrm{Hм.}$

Скорость глутатионредуктазной реакции (ГР) определяли по методу, представленному в [8] в кварцевых кюветах при спектрофотометрической регистрации убыли НАДФН при $\lambda=340$ нм. Инкубационная среда состояла из буфера $0,05 \mathrm{M}$ трис-(оксиметил)-аминометан - $\mathrm{HCl}$, содержащего 0,25 mM ЭДТА - $\mathrm{Na}$, pH $-7,4$ и 0,033 М глутатиона окисленного (Г-SS-Г). Реакцию запускали добавлением 2mM NAДФН. Продолжительность записи реакции - 1-1,5 мин.

Скорость ацетилхолинэстеразной реакции определяли по модифицированному методу с использованием реактива Эллмана [8] с автоматической регистрацией образующегося в результате реакции соединения 5-тио-2-нитробензойной кислоты при $\lambda=412$ нм. Концентрация эфирных масел и их фракций составляла 10 мкг/мл.

\section{Результаты и обсуждение}

Результаты определения биологической активности исследованных образцов эфирных масел с использованием биотест-систем in vitro приводятся в таблице 1.

Полученные данные биологической активности (табл. 1) показывают высокую чувствительность ферментных тест-систем к исследуемым эфирным маслам. Эфирное масло, полученное из сырья пихты и сосны сибирской, увеличивает скорость реакции фермента системы антиоксидантной защиты КАТ, в 2,5 и 3 раза соответственно.

Образцы эфирных масел еще в большей степени активируют другой фермент антиоксидантной защиты - ГР: эфирное масло пихты увеличивает скорость реакции ГР более чем в 8 раз относительно контроля, а эфирное масло сосны - в 3,5 раза. По-видимому, такая активация различных ферментов антиоксидантной защиты обусловлена реакционной способностью химических соединений эфирных масел, в особенности имеющих двойные связи (камфен, $\alpha$-пинен, лимонен и др.). Поскольку активный центр КАТ стерически предотвращает проникновение более крупных молекул, чем $\mathrm{H}_{2} \mathrm{O}_{2}$, которыми и являются компоненты эфирного масла, то, вероятно, структурные соединения, входящие в состав эфирных масел, взаимодействуют с теми участками апофермента и/или кофермента, которые не входят в состав активного центра.

Ферменты антиоксидантной защиты ГР и КАТ играют ключевую роль в обеспечении регуляции свободно радикального окисления клетки и могут служить мишенью для лекарственных средств [7].

Таблица 1. Влияние исследованных образцов эфирного масла на скорость глутатионредуктазной, каталазной и ацетилхолинэстеразной реакции

\begin{tabular}{l|c|c|c}
\hline \multicolumn{1}{c|}{ Эфирное масло } & \multicolumn{3}{|c}{ Скорость ферментативной реакции, \% } \\
\cline { 2 - 4 } & ГР & КАТ & АХЭ \\
\hline Контроль (скорость реакции фермента без добавления эфирного масла) & 100,0 & 100,0 & 100,0 \\
Пихты сибирской & 873,9 & 231,6 & 26,89 \\
Сосны сибирской & 359,9 & 292,2 & 16,9 \\
\hline
\end{tabular}


Поскольку активация ферментов КАТ и ГР при действии БАВ коррелирует с наличием антиоксидантных свойств [9], следовательно, эфирное масло пихты и сосны сибирской обладает ярко выраженными антиоксидантными свойствами и способствует обезвреживанию свободных радикалов еще до развития эффекта повреждения биомолекул в организме.

АХЭ - фермент, катализирующий реакцию гидролиза природного нейромедиатора ЦНС ацетилхолина. Блокирование или ингибирование АХЭ в организме человека приводит к накоплению ацетилхолина в органах и тканях, усиливая его действие как возбуждающего медиатора в нервно-мышечном соединении (возбуждение нервных клеток, сокращение мышц). Пихтовое и сосновое эфирные масла оказывают противоположный эффект на скорость реакции АХЭ. Так, при добавлении исследуемых эфирных масел значительно замедляется скорость реакции АХЭ, при этом происходит ингибирование этого фермента практически на $80 \%$ (табл.1). Таким образом, эфирное масло пихты и сосны сибирской может стимулировать деятельность нервной системы человека, в частности, улучшает концентрацию внимания, ускоряет восстановление после стресса, болезней, снятие напряжения. Ингибиторы холинэстеразы используют при лечении мышечных дистрофий.

Активация КАТ и ГР в сочетании с ингибированием АХЭ позволяет делать вывод о наличии ноотропных свойств в исследуемых эфирных маслах [9].

Так как химический состав в процессе отгонки эфирного масла может меняться [2-5], то было важно сравнить биологическую активность отобранных фракций эфирного масла, полученного из сырья сосны и пихты сибирской, данные представлены в таблицах 2 и 3 соответственно.

Результаты определения скорости ферментативных реакций при действии отобранных в процессе отгонки порций эфирного масла пихты сибирской показывают, что при добавлении каждой последующей полученной фракции биологическое действие эфирного масла на фермент снижается, т.е. взаимодействие содержащихся компонентов в отобранных пробах и фермента становится слабее, что косвенно свидетельствует об изменении химического состава выделенных фракций. Так, при анализе первой отобранной пробы эфирного масла скорость реакции ферментов антиоксидантной защиты КАТ и ГР максимально высокая: 165,70 и 908,02\% соответственно, но при добавлении последней фракции скорость реакции этих ферментов уменьшается до $111,41 \%$ (КАТ) и $191,44 \%$ (ГР).

Данные о скорости реакции АХЭ (табл. 2) также указывают на снижение биологического действия этого эфирного масла в процессе отгонки. Как видно из таблицы 2, фракция масла, полученная в начале отгонки в наибольшей степени ингибирует фермент, при добавлении последующих порций пихтового эфирного масла ингибирование фермента снижается, в результате чего скорость реакции АХЭ приближается к значению контроля.

Таким образом, с увеличением времени выделения или отгонки эфирного масла, количество химических компонентов и их концентрация становится меньше, а биологическая активность эфирного масла пихты сибирской снижается.

Таблица 2. Биологическая активность отдельных фракций эфирного масла пихты сибирской

\begin{tabular}{l|c|c|c|c|c|c}
\hline \multirow{2}{*}{\multicolumn{1}{c|}{ Показатель }} & \multicolumn{7}{|c}{ Скорость ферментативных реакций, \% } \\
\cline { 2 - 7 } & Фракция 1 & Фракция 2 & Фракция 3 & Фракция 4 & Фракция 5 & Цельное масло \\
\hline Скорость реакции КАТ & 165,70 & 167,81 & 164,82 & 113,54 & 111,41 & 231,61 \\
Скорость реакции ГР & 908,02 & 864,43 & 310,23 & 306,12 & 191,44 & 873,92 \\
Скорость реакции АХЭ & - & 13,90 & 12,85 & 68,82 & 53,71 & 26,891 \\
Контроль (скорость реакции & 100,00 & 100,00 & 100,00 & 100,00 & 100,00 & 100,00 \\
фермента без добавления & & & & & & \\
эфирного масла) & & & & & & \\
\hline
\end{tabular}

Таблица 3. Биологическая активность отдельных фракций эфирного масла сосны сибирской

\begin{tabular}{l|c|c|c|c|c|c}
\hline \multirow{2}{*}{\multicolumn{1}{c|}{ Показатель }} & \multicolumn{7}{c}{ Скорость ферментативных реакций, \% } \\
\cline { 2 - 7 } & Фракция 1 & Фракция 2 & Фракция 3 & Фракция 4 & Фракция 5 & Цельное масло \\
\hline Скорость реакции КАТ & 122,8 & 107,2 & 159,8 & 380,8 & 295,6 & 292,2 \\
Скорость реакции ГР & 590 & 490,2 & 483 & 96,6 & 275,3 & 359,9 \\
Скорость реакции АХЭ & 21,9 & 34,1 & 33,9 & 55,8 & 74,9 & 16,9 \\
Контроль (без добав- & 100,00 & 100,00 & 100,00 & 100,00 & 100,00 & 100,00 \\
ления эфирного масла) & & & & & & \\
\hline
\end{tabular}


Как следует из данных таблицы 3, при добавлении в инкубационную среду каждой последующей полученной фракции в процессе отгонки изменение биологической активности эфирного масла сосны сибирской выражается не только в снижении скорости реакции ГР и АХЭ реакции, но в отличие от пихтового эфирного масла, проявляется способность увеличивать скорость реакции КАТ.

Так, при добавлении первой фракции эфирного масла сосны сибирской скорость ферментативной реакции КАТ становится выше контроля только на 22,8\%, составляя 122,8\%, но при анализе последней полученной фракции активность эфирного масла значительно увеличивается, активизируя реакцию КАТ до 295,6\%, что почти в 2,5 раза выше, чем показатель масла из первой фракции и в 3 раза выше показателя контроля.

Таким образом, данные таблицы 3, свидетельствуют о снижении биологической активности эфирного масла сосны в течение времени его выделения, в то же время при добавлении этих же фракций скорость реакции другого фермента тест-системы in vitro КАТ, наоборот, показывает увеличение биологического действия отобранных проб. Такое увеличение и снижение биологической активности эфирного масла сосны сибирской в зависимости от выбранных ферментов тест-системы для анализа фракций, возможно определяется уменьшением содержания компонентов взаимодействующих с ГР и АХЭ и увеличением концентрации соединений присоединяющихся к КАТ, в процессе его отгонки.

\section{Bыводы}

Показана возможность применения тест-систем in vitro для выявления биологической активности эфирных масел и сравнительного анализа различных фракций эфирного масла.

Установлено, что эфирные масла пихты и сосны сибирской активирует фермент КАТ и ГР и ингибирует АХЭ, что свидетельствует о наличии в исследуемых эфирных маслах антиоксидантных и ноотропных свойств.

В процессе выделения из сырья биологическая активность эфирного масла может как увеличиваться, так и снижаться, что определяется влиянием химических соединений в составе отдельных фракций эфирного масла.

\section{Список литературы}

1. Белоусова Н.И. Состав эфирных масел багульников флоры Сибири и российского Дальнего Востока : дис. ... канд. хим. наук. Новосибирск, 1996. 140 с.

2. Алякин А.А., Качин С.В., Ефремов А.А., Поляков Н.А. Динамика выделения и физико-химические показатели эфирного масла багульника болотного // Вестник Красноярского государственного университета. 2006. №2. С. 105-107.

3. Ефремов Е.А., Ефремов А.А. Компонентный состав эфирного масла июльской лапки пихты сибирской Красноярского края // Химия растительного сырья. 2010. №2. С. 135-138.

4. Ефремов Е.А., Ефремов А.А. Компонентный состав эфирного масла октябрьской лапки пихты сибирской Красноярского края // Химия растительного сырья. 2010. №3. С. 121-124.

5. Нарчуганов А.Н., Струкова Е.Г., Ефремов А.А. Компонентный состав эфирного масла сосны сибирской (Pinus Sibirica) // Химия растительного сырья. 2011. №4. С. 103-108.

6. Ефремов А.А., Зыкова И.Д., Дрожжина М.В. Изменения компонентного состава и физико-химических показателей эфирного масла корневищ Acorus Calamus (Araseae) в зависимости от продолжительности его выделения // Растительные ресурсы. 2011. Т. 47, вып. 1. С. 118-123.

7. Быков В.А., Дубинская В.А., Ребров Л.Б., Минеева М.Ф., Скуридин С.Г., Евдокимов Ю.М. Комплексный подход к изучению механизмов действия противомикробных и противовирусных средств // Химикофармацевтический журнал. 2008. Т. 42, №3. С. 3-8.

8. Beutler E. Red cell metabolism, Churchill. Livingson, N-Y. 1986. Pp. 60-69.

9. Патент 2181892 (РФ). Способ выявления веществ, обладающих антиоксидантными свойствами, in vitro / В.А. Дубинская, В.А. Быков, М.Ф. Минеева. 2001.

Поступило в редакциию 5 мая 2012 г. 
Dubinskaya V.A. ${ }^{l}$, Polyakov N.A. ${ }^{{ }^{*},}$ Efremov A.A. ${ }^{2}$, Efremov E.A. ${ }^{2}$ DETERMINATION OF BIOLOGICAL ACTIVITY OF ESSENTIAL OILS BY THE TEST-SYSTEM IN VITRO

${ }^{\text {I} A l l-R u s s i a}$ Research Institute of Medicinal and Aromatic Plants, st. Krasina, 2, Moscow, 123056 (Russia),

e-mail: polakov@yandex.ru

${ }^{2}$ Siberian Federal University, st. Svobodnyi, 79, Krasnoyarsk, 660041 (Russia), e-mail: AEfremov@sfu-kras.ru

The possibility of using enzymatic test systems in vitro to determine the biological activity of essential oils and comparative analysis of different fractions of essential oil were shown. Essential oil of Abies Sibirica and Pinus Sibirica activated the enzymes catalase and glutationreductase and inhibited acetylcholinesterase, due to antioxidant and neuroprotective properties of essential oil. It was found that in the process of isolation procedure of essential oils from raw materials, biological activity of essential oils can either increase or decrease, what connecting with composition of individual fractions of essential oil.

Keywords: Abies Sibirica, Pinus Sibirica, essential oil, enzymatic test systems in vitro, biological activity.

\section{References}

1. Belousova N.I. Sostav efirnykh masel bagul'nikov flory Sibiri i rossiiskogo Dal'nego Vostoka: dis. ... kand. khim. nauk. [The composition of the essential oils of wild rosemary flora of Siberia and the Russian Far East: Ph.D. in Chemistry]. Novosibirsk, 1996,140 p. (in Russ.).

2. Aliakin A.A., Kachin S.V., Efremov A.A., Poliakov N.A. Vestnik Krasnoiarskogo gosudarstvennogo universiteta, 2006, no. 2, pp. 105-107. (in Russ.).

3. Efremov E.A., Efremov A.A. Khimiia rastitel'nogo syr'ia, 2010, no, 2, pp. 135-138. (in Russ.).

4. Efremov E.A., Efremov A.A. Khimiia rastitel'nogo syr'ia, 2010, no. 3, pp. 121-124. (in Russ.).

5. Narchuganov A.N., Strukova E.G., Efremov A.A. Khimiia rastitel'nogo syr'ia, 2011, no. 4, pp. 103-108. (in Russ.).

6. Efremov A.A., Zykova I.D., Drozhzhina M.V. Rastitel'nye resursy, 2011, vol. 47, no. 1, pp. 118-123. (in Russ.).

7. Bykov V.A., Dubinskaia V.A., Rebrov L.B., Mineeva M.F., Skuridin S.G., Evdokimov Iu.M. Khimikofarmatsevticheskii zhurnal, 2008, vol. 42, no. 3, pp. 3-8. (in Russ.).

8. Beutler E. Red cell metabolism, Churchill. Livingson, N-Y., 1986, pp. 60-69.

9. Patent 2181892 (RU). 2001. (in Russ.).

Received May 5, 2012

Revised May 25, 2013

\footnotetext{
* Corresponding author.
} 
